\title{
TINJAUAN KECERDASAN YUSUF BERDASARKAN KECERDASAN SPIRITUAL (SPIRITUAL INTELLIGENCE), KECERDASAN EMOSIONAL (EMOTIONAL INTELLIGENCE), KECERDASAN INTELEKTUAL (INTELLECTUAL INTELLEGENCE) DAN KETANGGUHAN (ADVERSITY QUOTIENT)
}

\author{
Agus Purwanto \\ (Dosen Sekolah Tinggi Teologi Bethel Samarinda)
}

\begin{abstract}
One of the people chosen by God to prepare a country and its people in fulfilling His plan, that person was Joseph. Joseph as the maker of history and the link that connects the Book of Genesis to the Book of Exodus, was chosen by God to fulfill His plan, not by going through a smooth road, but there are many steep and abyss as a life experience to go through. The inclusion and guidance of God, made Joseph have something "special", namely intelligence. Intelligence is not only in terms of intellectual intelligence, but various intelligence is given by God to enable Joseph to live his life. This paper reviews Joseph's Intelligence based on Spiritual Intelligence, Emotional Intelligence, Intellectual Intelligence and Adversity Quotient. Joseph's life experience, privileges and obedience ultimately brought success in fulfilling God's plan to preserve the life of a nation.
\end{abstract}

Keywords: Spiritual Intelligence, Emotional Intelligence, Intellectual Intelligence, Toughness

\section{A. PENDAhuluan}

Yusuf adalah anak ke-sebelas Yakub yang dilahirkan oleh Rahel. Yakub, ayahnya lebih mengasihi Yusuf dari semua anaknya yang lain. Salah satu bentuk dimana Yakub lebih mengasihi Yusuf dari pada anak-anaknya yang lain, ia menyuruh membuat jubah yang sangat indah bagi Yusuf. Hal ini membuat saudara-saudara Yusuf iri hati dan memperlakukan Yusuf dengan tidak ramah. Sebagai anak yang lebih dikasihi ayahnya, Yusuf mengalami berbagai masalah dalam kehidupannya yang membuat seolah-olah kehidupannya menjadi buruk.

Alkitab menceritakan bahwa Yusuf sejak masa remajanya banyak sekali mengalami masalah. Tetapi bila dicermati, maka akan terlihat bahwa semua masalah yang dihadapi Yusuf merupakan suatu "proses pembentukan" dari Allah untuk mempersiapkan Yusuf sebagai pemimpin, tidak hanya bagi bangsanya, yaitu Israel, tetapi juga pemimpin di negeri orang lain. Tuhan menempa Yusuf dengan berbagai masalah tidak hanya untuk menjadikannya sebagai seorang pemimpin, tetapi juga sebagai cara Tuhan untuk menjadikan Yusuf sebagai alat untuk memasyhurkan dan memuliakan nama Tuhan. Kepribadian serta kecerdasan yang dimiliki Yusuf 
membuat kehidupannya berhasil untuk menggenapi segala sesuatu yang telah direncanakan oleh Tuhan untuk kemuliaan nama-Nya. Tulisan ini disusun untuk mengulas Kecerdasan yang dimiliki oleh Yusuf, yang meliputi Kecerdasan Intelektual (Intellectual Intelligence), Kecerdasan Emosi (Emotional Intelligence), Kecerdasan Spiritual (Spiritual Intelligence), dan Ketangguhan menghadapi kesulitan (Adversity Quotient).

\section{B. METODE PENELITIAN}

Metode penelitian yang digunakan adalah kualitatif biblika. Pendekatan yang berfokus pada penggalian makna teks, dengan pendekatan analisa historis dan analisa gramatika. ${ }^{1}$ yang digunakanan dalam melaksanakan penelitian ini ialah metode penelitian studi Pustaka. Menurut Mestika Zed perbedaan utama antara riset kepustakaan dan riset lapangan hanyalah terletak pada tujuan, fungsi dan kedudukan studi pustaka dalam masing-masing penelitian itu. Dalam riset lapangan, penelusuran pustaka terutama dimaksudkan sebagai langakah awal untuk menyiapkan kerangka penelitian dan proposal guna memperoleh informasi penelitian sejenis, memperdalam kajian teoritis atau mempertajam metodologi. Sedangkan riset pustaka, penelusuran pustaka lebih daripada sekedar melayani fungsi-fungsi yang disebutkan di atas. Riset pustaka memanfaatkan sumber perpustakaan untuk memperoleh data penelitiannya. ${ }^{2}$

\section{PEMBAHASAN}

Kecerdasan dapat diartikan kesempurnaan perkembangan akal budi seorang manusia untuk berfikir, mengerti, tajam pikiran dan sempurna pertumbuhan tubuhnya. Kecerdasan bisa juga diartikan sebagai kemampuan general manusia untuk melakukan tindakan-tindakan yang mempunyai tujuan tertentu dengan berpikir secara rasional. Howard Garner, seorang psikolog dari Harvard University, dalam bukunya Frames of Mind, 1983, memperkenalkan Multiple Intelegence (Kecerdasan Majemuk), yang meliputi kecerdasan logis-matematis, kecerdasan linguistik-verbal, kecerdasan visual-spatial, kecerdasan musical, kecerdasan kinestic, kecerdasan

\footnotetext{
${ }^{1}$ Gidion Gidion, "STUDI BIBLIKA KORELASI TEOLOGI PAULUS DAN TEOLOGI YAKOBUS TENTANG IMAN DAN PERBUATAN IMAN," Shift Key: Jurnal Teologi dan Pelayanan (2018).

${ }^{2}$ Mestika Zed, Metode Peneletian Kepustakaan (Jakarta: Yayasan Obor Indonesia, 2008), 1-2.
} 
interpersonal, kecerdasan intrapersonal dan kecerdasan naturalis. ${ }^{3}$ Garner menyatakan bahwa kecerdasan seseorang lebih berkaitan dengan kapasitas: (1) memecahkan masalah dan (2) menciptakan produk. ${ }^{4}$ Kecerdasan logis-matematis dan linguistik, diklasifikasikan sebagai Kecerdasan Inteligensi (Intellectual Inteligence), Kecerdasan Interpersonal dan Intrapersonal sebagai Kecerdasan Emosi (Emotional Intelligence).

\section{Kecerdasan Inteligensi (Intellectual Intelligence).}

Kecerdasan inteligensi (intelligence quotient, disingkat $I Q$ ) adalah istilah umum yang digunakan untuk menjelaskan sifat pikiran yang mencakup sejumlah kemampuan, seperti kemampuan menalar, merencanakan, memecahkan masalah, berpikir abstrak, memahami gagasan, menggunakan bahasa, dan belajar. Kecerdasan erat kaitannya dengan kemampuan kognitif (cara otak berpikir, mengingat, belajar) yang dimiliki oleh individu. Yang artinya ukuran kemampuan Intelektual, analitis (kemampuan menganalisa), logika dan ratio seseorang.

Saat Yusuf ditangkap dan kemudian di buang ke sumur kosong, ia tidak melakukan reaksi yang negatif, seperti berteriak-teriak atau memaki saudara-saudaranya yang bisa membuat mereka tersulut emosinya. Ini berkaitan dengan kemampuan Yusuf dalam menalar keadaan dan memahami masalah. Dengan tingkat kecerdasan emosional yang cukup baik, ia juga mampu merasakan dengan emosinya tentang orang lain, dimana ia merasakan bahwa saudara-saudaranya sangat membencinya dan mungkin saat itu juga sedang dikuasai amarah. Kecerdasan Intelegensia Yusuf tidak hanya berkaitan dengan kemampuan berpikir secara matematika saja tetapi Yusuf melengkapi dengan kemampuan untuk berpikir secara nalar (logic), kemampuan memahami keadaan dan juga kemampuan dalam menggunakan emosinya. Semua ini dimiliki oleh Yusuf karena ia juga memiliki kemampuan emosional yang baik.

Kecerdasan intelektual Yusuf lainnya, terlihat ketika ia berada di rumah seorang pegawai istana Firaun, kepala pengawal raja yang bernama Potifar (Kejadian 37:36). Tidak mudah bagi seorang pegawai kepercayaan raja Mesir dan memiliki kekuasaan yang besar untuk memberikan kepercayaan kepada seorang asing, orang Ibrani yang masih muda, kalau ia tidak memiliki alasan yang kuat.Allah Israel yang berdaulat terlibat erat dalam kehidupan Yusuf. Ia

\footnotetext{
${ }^{3}$ Thomas Amstrong, Sekolah Para Juara (Bandung: PT. Mizan Pustaka, 2004), 2-4.

${ }^{4}$ Amstrong, Sekolah Para Juara.
} 
yang mengawalnya. Ia memberikan kecakapan untuk berbahasa Mesir. Pada puncak segala hal itu, Ia yang memberikan kasih dalam mata Potifar kepadanya. Sudah jelas, Allah adalah rahasia kesuksesan Yusuf. ${ }^{5}$ Yusuf tidak perlu memberitahukan kepada Potifar tentang kemampuannya atau tentang Tuhan menyertai dia, Potifar bisa melihatnya sendiri; Setelah dilihat oleh tuannya, bahwa Yusuf disertai TUHAN dan bahwa TUHAN membuat berhasil segala sesuatu yang dikerjakannya, maka Yusuf mendapat kasih tuannya, dan ia boleh melayani dia; kepada Yusuf diberikannya kuasa atas rumahnya dan segala miliknya diserahkannya pada kekuasaan Yusuf. (Kejadian 39:3-4).

Bagi orang lain yang memiliki kedudukan jauh lebih rendah dari seorang tuan (Yusuf sebagai pembantu), mungkin dengan mudah mau menuruti ajakan isteri Potifar untuk tidur dengannya karena takut kehilangan pekerjaan atau untuk mendapatkan imbalan yang lain. Berbeda dengan Yusuf, ia dengan kecerdasan intelektual yang dimiliki menggunakan nalarnya bahwa kalau ia menuruti ajakan isteri majikannya, tidak saja Tuhan tahu, tapi pastilah suatu saat apa yang dia perbuat (Skandal) itu akan dikuakan oleh Tuhan dan akan membuat dirinya dipermalukan dan reputasinya rusak.

Di Kejadian 39:22 disebutkan bahwa Yusuf tidak hanya diserahi tugas mengurus orangorang yang ditahan, tetapi juga segala pekerjaan yang harus dilakukan di dalam penjara, bahkan kepala penjara tidak lagi mencampuri urusan yang telah dipercayakan kepada Yusuf. Ini menunjukan bahwa kepala penjara mempercayakan pekerjaan pengurusan para tahanan dan pekerjaan dalam penjara sepenuhnya kepada Yusuf. Pekerjaan pengurusan keperluan-keperluan dalam penjara tentu bukanlah hal yang mudah bagi seorang anak yang masih muda seperti Yusuf, namun faktanya Kepala Penjara mempercayakan hal itu kepada Yusuf. Kepala Penjara pastilah mengetahui bagaimana Yusuf mampu melakukan pekerjaan pengurusan rumah Potifar dan kemampuan mengatur orang-orang.

Memilih orang-orang berdasarkan kemampuan untuk melaksanakan pekerjaan diatas saja sudah memerlukan keahlian. Ketika ia diserahi untuk mengurus para tahanan dan pekerjaan penjara, Yusuf tidak hanya dituntut untuk mampu memahami karakter orang, tetapi juga harus memiliki kecerdasan yang beragam, yaitu untuk menalar, melihat keadaan, merencanakan tindakan, mengorganisir, memahami masalah, memiliki gagasan, kemampuan untuk mau terus

\footnotetext{
${ }^{5}$ Swindoll, Yusuf - Seorang Yang Berintergritas Dan Pengampun, 47-48.
} 
belajar dan juga kemampuan dalam menggunakan bahasa yang tepat dalam menghadapi orangorang yang frustasi sehingga tidak menyebabkan emosi orang lain tersulut. Semua ini memerlukan tingkat kecerdasan yang tinggi.

Kecerdasan Intelektual Yusuf terlihat sangat jelas ketika ia memberikan saran atau solusi yang sangat baik setelah ia mengartikan mimpi Firaun tentang akan terjadinya masa tujuh tahun kelimpahan dan masa tujuh tahun kelaparan. (Kejadian 41:33-36). Dengan tuntunan Roh Tuhan, Yusuf benar-benar memperlihatkan kecerdasan yang luar biasa. Ia memberikan saran-saran kepada raja, pertama mencari seorang yang berakal budi dan bijaksana untuk menjadi penguasa atas tanah Mesir, kedua menempatkan para penilik untuk memungut seperlima dari hasil tanah Mesir pada saat musim kelimpahan, ketiga mengumpulkan bahan makanan dan gandum pada masa kelimpahan dan menyimpannya dan keempat, yaitu mengelola bahan makanan itu pada waktu masa tujuh tahun kelaparan.

Kecerdasan yang luar biasa pada diri Yusuf, membuat Firaun mengangkatnya menjadi seorang yang dipercaya untuk menjadi penguasa atas tanah Mesir. Setelah Yusuf dilantik oleh Firaun, maka dengan segera Yusuf melaksanakan semua usulan yang pernah disampaikan kepada raja. Ia mulai mengumpulkan segala makanan dan gandum lalu menimbunnya di kota-kota selama masa tujuh tahun kelimpahan itu. Jumlah bahan makanan yang ditimbun oleh Yusuf bertumpuk-tumpuk dan tak terhitung banyaknya. Kecerdasan Yusuf dalam hal finansial yang dianugerahkan oleh Tuhan sangatlah luar biasa, di masa tujuh tahun kelimpahan ia mengumpulkan bahan makanan dan menimbunnya di kota-kota. Ketika masa tujuh tahun kelaparan tiba ia menjual bahan makanan yang telah dikumpulkannya kepada orang-orang Mesir dan bangsa lain. Hasil penjualan bahan makanan, baik berupa uang, ternak, tanah ladang itu menjadi milik Firaun dan ini membuat raja Firaun sangatlah kaya raya.

Dari ulasan tentang kecerdasan intelektual Yusuf, nampak jelas daya kreativitas atau kecerdasan kreativitas yang dimiliki Yusuf. Justru ditengah tengah kesulitan, Yusuf memunculkan gagasan-gagasan yang kreatif untuk menyikapi situasi dan menjadikan tantangan sebagai suatu peluang. Kecerdasan Intelektual Yusuf, tidak hanya menunjukan kemampuan intelektual, logika, ratio dan daya nalarnya, tetapi terlihat adanya perpaduan yang kuat antara kecerdasan intelektual, kecerdasan emosi dan kecerdasan spiritual yang dimiliki oleh Yusuf. 


\section{Kecerdasan Emosional (Emotional Intelligence/Emotional Quotient).}

Emotional Quotient (EQ) atau kecerdasan emosi adalah kemampuan yang dimiliki seseorang dalam menyadari munculnya perasaan dalam diri sendiri atau dalam diri orang lain dan kemudian secara sadar memilih mengakomodasi perasaan tersebut. ${ }^{6}$ Kecerdasan Emosi dapat dimaknai sebagai kemampuan yang dimiliki seseorang dalam menyadari munculnya perasaan dalam diri sendiri atau dalam diri orang lain dan kemudian secara sadar memilih mengakomodasi perasaan tersebut. Kecerdasan emosional (EQ) merupakan kemampuan pengendalian diri untuk tidak terpengaruh situasi lingkungan kearah negatif. Kecerdasan emosi terkait dengan kemampuan untuk memotivasi diri sendiri agar mampu bertahan dengan mengendalikan dorongan hati untuk tidak bertindak negatif, mampu mengatur suasana hati dan menjaga agar tidak melumpuhkan kemampuan berpikir dan membaca perasaan orang lain, serta mampu mengendalikan dan memimpin diri dari pengaruh situasi lingkungan sekitarnya.

Sama halnya dengan Kecerdasan Spiritual, Kecerdasan Emosional pada diri Yusuf juga tidak muncul begitu saja. Proses pembentukan Kecerdasan Spiritual pada diri Yusuf memampukan dia untuk mengendalikan diri atau mengelola emosinya. Itu sebagai gambaran bahwa Roh Allah yang ada pada diri Yusuf memampukan atau memberdayakan Yusuf untuk memiliki buah Roh sebagaimana di tuliskan dalam Galatia 5:22-23, dimana Yusuf memiliki Roh Pengendalian diri, yaitu mampu mengendalikan emosinya. Pengendalian diri yang ada pada diri Yusuf memberikan makna bahwa ia juga memiliki delapan buah Roh yang lain seperti Kasih, sukacita, damai sejahtera, kesabaran, kemurahan, kebaikan, kesetiaan, kelemahlembutan. Alkitab mencatat bagaimana kondisi emosi Yusuf dalam menanggapi sesuatu yang terjadi pada dirinya. Beberapa hal yang akan diulas diantaranya :

Saudara-saudara Yusuf membenci dirinya karena orang tua mereka lebih mengasihi Yusuf daripada saudara-saudaranya. Puncak dari kebencian mereka kepada Yusuf adalah pada saat Yusuf menyampaikan dua mimpinya kepada orang tua dan saudara-saudaranya. (Kejadian $37: 8$ dan 11). Sebagai seorang anak yang dibenci oleh saudara-saudaranya, pastilah itu merupakan suatu hal yang sangat tidak mengenakan dan pasti akan merupakan tekanan batin bagi Yusuf. Alkitab memang tidak menceritakan bagaimana kondisi emosi Yusuf ketika ia harus mengalami tekanan batin karena dibenci oleh saudara-saudaranya. Dari Kejadian 37 : 13-17,

\footnotetext{
${ }^{6}$ Josua Iwan Wahyudi, Emotion For Success (Bandung: Visi Press, 2010), 46.
} 
ketika Yusuf disuruh oleh ayahnya untuk melihat saudara-saudaranya yang sedang menggembalakan ternak di padang, terlihat bahwa Yusuf tidak punya prasangka apapun terhadap saudara-saudaranya. Tidak tidak memiliki rasa benci atau tidak suka sebagimana saudarasaudaranya membenci dia. Dia dengan tulus memenuhi perintah bapanya untuk mencari saudaranya sampai ke Dotan. Hal ini menggambarkan, sekalipun Yusuf masih sangat muda, berumur tujuh belas tahun, dia sudah memiliki kemampuan untuk menjaga kondisi emosinya. Dia tidak memiliki rasa benci ataupun perasaan tidak suka kepada saudara-saudaranya yang membenci dia.

Dalam Kejadian 42:21, digambarkan bagaimana perasaan Yusuf ketika ia dimasukan oleh saudara-saudaranya ke dalam sumur kosong. Mereka berkata seorang kepada yang lain: "Betul-betullah kita menanggung akibat dosa kita terhadap adik kita itu: bukankah kita melihat bagaimana sesak hatinya, ketika ia memohon belas kasihan kepada kita, tetapi kita tidak mendengarkan permohonannya. Itulah sebabnya kesesakan ini menimpa kita." (Kejadian 42:21). Perasaan Yusuf saat itu, pastilah ia sangat sedih, ketakutan dan putus asa, merengek-rengek dan meminta belas kasihan kepada saudara-saudaranya. Mungkin juga ia berteriak-teriak untuk meminta agar saudara-saudaranya membebaskan dia. Tetapi semua itu tidak dihiraukan oleh saudara-saudaranya. Sekalipun dalam suasana hati yang sedih dan penuh kesesakan, Alkitab tidak menceritakan bahwa Yusuf mengeluarkan perkataan-perkataan yang jelek atau tidak senonoh untuk mengumpat atau memaki saudaranya yang bisa membuat emosi saudara-saudaranya tersulut. Itu menggambarkan salah satu kemampuan pengendalian emosi dari Yusuf dalam menghadapi situasi sulit.

Istri Potifar tertarik dengan sikap dan ketampanan Yusuf, sehingga ia selalu menggoda Yusuf untuk mau tidur dengan dia, namun Yusuf secara santun dan lugas mampu menggunakan kecerdasan emosinya untuk menolak ajakan isteri Potifar untuk berbuat zinah. Tetapi Yusuf menolak dan berkata kepada isteri tuannya itu: "Dengan bantuanku tuanku itu tidak lagi mengatur apa yang ada di rumah ini dan ia telah menyerahkan segala miliknya pada kekuasaanku, bahkan di rumah ini ia tidak lebih besar kuasanya dari padaku, dan tiada yang tidak diserahkannya kepadaku selain dari pada engkau, sebab engkau isterinya. Bagaimanakah mungkin aku melakukan kejahatan yang besar ini dan berbuat dosa terhadap Allah?" (Kejadian 39:8-9). Sampai akhirnya istri Potifar menjebak Yusuf dan membuat Potifar salah sangka dan 
memasukkan Yusuf ke dalam penjara. Dari ulasan diatas kita bisa melihat bagaimana Yusuf yang masih muda mampu menunjukan sikapnya yang tegas dan menjaga moralnya serta mampu mengendalikan emosinya untuk menolak ajakan istri Potifar untuk berzinah.

Sekalipun Yusuf mengalami kehidupan yang buruk, ia menunjukan sikap yang berbeda dengan para tahanan yang lain. Karakter, kecerdasan spiritual, emosi dan intelektualnya, membuat kepala penjara melihat perbedaan yang ada pada diri Yusuf. Yusuf menjadi kesayangan kepala penjara dan mempercayakan semua tahanan dan semua pekerjaan dalam penjara kepada Yusuf. Seorang tahanan seperti Yusuf yang menjadi kesayangan dan dipercaya oleh kepala penjara, pastilah ada dasarnya. Salah satu yang dilihat kepala penjara itu pastilah kematangan emosi yang dimiliki Yusuf. Kematangan emosi ini dapat dilihat dalam diri Yusuf ketika ia melihat juru minum dan juru roti sedang bermuram karena mimpi mereka. Kematangan emosi yang dimiliki Yusuf tidak membuatnya sombong dengan mengolok-olok orang yang sedang bermuram, justru Yusuf mampu menghibur mereka bahkan menanyakan mimpi yang mereka alami dan mengartikannya.

Pada waktu Yusuf dipanggil oleh Raja Firaun untuk mengartikan mimpinya, dicatat dalam Kejadian $41:$ 14, ia bercukur dan berganti pakaian lalu pergi menghadap Raja Firaun. Hal ini dilakukan oleh Yusuf karena umumnya penampilan orang-orang Mesir sangatlah berbeda dengan orang-orang Ibrani. Orang Mesir memotong rambutnya dengan rapi dan mencukur janggutnya. Ini berbeda dengan orang Ibrani yang secara umum membiarkan rambutnya panjang, berjambang dan berjanggut. Ini menggambarkan bahwa sekalipun Yusuf telah lama hidup di dalam penjara, ia tidak ingin di hadapan orang lain, khususnya raja bahwa ia nampak seperti orang yang frustasi atau orang yang sengsara. Yusuf ingin menyesuaikan diri dengan penampilan orang Mesir dan juga untuk menunjukan diri melalui penampilan fisiknya bahwa ia adalah orang yang tidak mengalami masalah dan tetap bersukacita, sekalipun ia selama ini dipenjara tanpa ada kesalahan. Ini menunjukan tingkat kecerdasan emosi Yusuf yang sangat baik.

Ketika Yusuf di hadapan raja dan diminta untuk mengartikan mimpi raja, Yusuf dengan santun juga mengatakan bahwa Tuhanlah yang akan memberikan arti mimpi itu. Yusuf juga tetap menjaga emosinya untuk tidak berkeluh kesah tentang nasibnya atau tentang kecurangan dari Juru Minum raja yang telah menipunya. Yusuf dapat mengontrol emosinya untuk tidak 
melakukan hal-hal negatif di hadapan Raja. Kemampuan mengendalikan emosinya membuat Yusuf bersikap tenang, saat menjawab dan mengartikan mimpi raja, bahkan Yusuf mampu untuk memberikan solusi kepada raja sebagai jalan keluar untuk menghadapi terjadinya tahun-tahun kelaparan yang akan datang. Seorang yang tidak memiliki kematangan emosi pastilah akan terlihat gentar di hadapan seorang raja. Ia tidak akan mampu menyampaikan saran mengenai cara yang harus dilakukan raja Firaun.

Kecerdasan Spiritual, Kecerdasan Emosi ditambah Kecerdasan Intelektual yang ada pada diri Yusuf bukanlah merupakan sesuatu yang tersembunyi, tetapi memancar keluar sehingga dapat dilihat dan dirasakan oleh orang lain. Ketika Firaun memandang bahwa apa yang disarankan Yusuf amatlah baik, maka Firaun melihat ada sesuatu kepribadian yang berbeda yang dimiliki oleh Yusuf sehingga ia mengatakan: "Mungkinkah kita mendapat orang seperti ini, seorang yang penuh dengan Roh Allah ?" Roh Allah memampukan Yusuf tidak hanya sebagai orang yang takut akan Tuhan, mengasihi Tuhan dan juga menaati perintahnya, tetapi Roh Allah juga memampukan Yusuf untuk memiliki kecerdasan, baik kecerdasan spiritual, emosi maupun kecerdasan intelektualnya.

Saat Firaun tiba-tiba mengangkat Yusuf yang tadinya adalah seorang tahanan, menjadi penguasa atas seluruh tanah Mesir, Yusuf tidaklah melonjak-lonjak kegirangan seperti seorang anak kecil atau berteriak-teriak seperti seseorang memenangi perlombaan, tetapi Yusuf digambarkan dalam Alkitab ia tetap menjadi pribadi yang rendah hati. Mengenai pengendalian diri yang dilakukan oleh Yusuf ini, Charles R. Swindoll, menuliskan :

Siapakah yang tidak terkesan oleh pengendalian diri yang dimiliki oleh Yusuf ? Dengan menolak memanipulasi saat yang tepat itu atau memberi petunjuk, ia hanya berdiri menunggu. Entah bagaimana, dalam kesendirian selama bertahun-tahun belakangan ini, ditinggalkan dan dilupakan di dalam penjara, ia telah belajar untuk membiarkan Tuhan melakukan cara-Nya, dalam waktu-Nya, demi tujuan-Nya ! Karena tidak mempunyai ambisi pribadi, Yusuf menolak untuk meninggikan dirinya. Betapa menyegarkan - betapa jarangnya !

Ia segera melakukan tugasnya dengan mengelilingi seluruh tanah Mesir dan mengumpulkan gandum untuk persediaan tujuh tahun masa kelaparan yang akan terjadi di Mesir. Ketika menjadi Penguasa Mesir, karakter, sifat maupun sikap Yusuf tidak berubah, ia tetap

${ }^{7}$ Charles R. Swindoll, Yusuf - Seorang Yang Berintergritas Dan Pengampun (Jakarta: Nafiri Gabriel, 2011), 101-102. 
rendah hati, taat dan takut akan Tuhan, serta mampu mengendalikan emosinya. Ia melakukan pekerjaan dan kekuasaannya dengan integritas, penuh tanggungjawab, berinovasi dan efisien.

Kecerdasan emosi Yusuf terlihat saat ia melihat dan bertemu dengan saudarasaudaranya, ia tidak meluapkan dendamnya atau melakukan tindakan sewenang-wenang. Yusuf "mengerjai" saudara-saudaranya yang tidak mengenali dirinya dengan seolah-olah ia terlihat marah. Sebagai seorang yang pernah disakiti, dihina, direndahkan dan dijual dan diperlakukan sebagai seorang budak, Yusuf yang saat ini sebagai seorang yang sangat berkuasa di Mesir dapat dengan mudah meluapkan dendamnya kepada saudara-saudaranya itu. Umur Yusuf saat bertemu saudara-saudaranya diperkirakan sekitar tigapuluh sembilan tahun, artinya sudah lebih dari duapuluh tahun dia mengalami kehidupan yang buruk dengan menjadi orang asing di negeri Mesir dan harus hidup terpisah dari orang tua dan saudara-saudaranya serta negerinya. Sekalipun saat itu Yusuf sedang memendam perasaannya yang campur aduk, tetapi ia dengan cerdik mampu menggunakan gaya bahasa yang sulit untuk ditebak, ia menanyakan tentang keadaan ayahnya dan juga adik kesayangannya, yaitu Benyamin. Yusuf menjaga perasaannya untuk tidak sampai terlihat menangis di hadapan saudara-saudaranya. Semua perasaan itu ia tahan dan baru ia meluapkan ketika ia masuk di dalam kamarnya, sehingga tidak ada seoraangpun yang melihat Yusuf menangis. Dalam kisah ini, terlihat bahwa Yusuf memiliki kemampuan pengendalian emosi yang sungguh sangat luar biasa.

Ketika Yusuf memperkenalkan siapa sesungguhnya dirinya, nampak kematangan emosinya yang sangat luar biasa. Kepada saudara-saudaranya yang sedang bingung dan dicekam rasa bersalah dan ketakutan, gemetar serta mengira bahwa Yusuf pasti akan membalaskan perbuatan yang pernah mereka lakukan, Yusuf justru mampu meredakan ketakutan mereka. Ia meminta saudara-saudaranya mendekat kepadanya dan memeluk mereka satu persatu dan merekapun bertangis-tangisan, bahkan setelah itu Yusuf menjamu saudara-saudaranya itu dengan makan bersama. Bahkan Yusuf menghibur mereka dengan mengatakan : "Tetapi sekarang, janganlah bersusah hati dan janganlah menyesali diri, karena kamu menjual aku ke sini, sebab untuk memelihara kehidupanlah Allah menyuruh aku mendahului kamu." (Kejadian 45:5).

Ketika ayah dan sanak saudaranya tiba di Mesir, Yusuf telah menyediakan tempat yang subur dan banyak rumput untuk mereka. Semua itu dilakukan dengan kesadaran bahwa ia bertanggungjawab atas kehidupan sanak saudaranya. Yusuf tidak mendendam pada sanak 
saudaranya yang telah memperlakukan dirinya dengan tidak baik, sehingga ia harus lama mengalami kehidupan yang buruk tetapi dengan kematangan emosinya, Yusuf menunjukan tanggungjawabnya untuk memelihara mereka. Bahkan ketika Yakub telah meninggal dan saudara-saudaranya merasa ketakutan kalau-kalau Yusuf akan membalas dendam atas perbuatan mereka dan menyuruh orang datang untuk memberikan ampun atas kesalahan mereka, justru Yusuf menangis. Artinya bahwa Yusuf tidak mengingat lagi apa yang dilakukan oleh saudarasaudaranya dan dia terharu bahwa saudara-saudaranya merasa sangat ketakutan kepada dia. Juga ketika saudara-saudara Yusuf datang menghadap kepada dia dan sujud sambil berkata : "Kami datang untuk menjadi budakmu" (Kejadian 50:18), Yusuf semakin terharu dan ia mencoba untuk menenangkan mereka dengan berkata : "Janganlah takut, sebab aku inikah pengganti Allah? Memang kamu telah mereka-rekakan yang jahat terhadap aku, tetapi Allah telah merekarekakannya untuk kebaikan, dengan maksud melakukan seperti yang terjadi sekarang ini, yakni memelihara hidup suatu bangsa yang besar.” (Kejadian 50:19-20).

"Bukan talenta-talenta luar biasa yang diberkati oleh Tuhan sedemikian besar, melainkan keserupaan/menjadi serupa dengan Yesus. Pelayan yang kudus adalah senjata yang ampuh di tangan Tuhan”. (Robert Murray McChayne). ${ }^{8}$ Dari ulasan tentang Emotional Quotient atau kecerdasan emosi pada diri Yusuf, terlihat bahwa Yusuf sungguh memiliki sikap pengampun seperti halnya Allah. Kecerdasan emosinya bukanlah dimulai dari kecerdasan Intelektual (Intelektual Quotient), namun justru dari kecerdasan spiritual. Kematangan rohaninya membawa Yusuf memiliki kecerdasan emosi yang luar biasa dalam menghadapi situasi yang sulit. Ia tidak mendendam atas perbuatan saudara-saudaranya atau orang-orang yang pernah menyakiti dirinya, misalnya isteri Potifar yang telah memfitnah dia, bahkan dalam perasaan yang mengharukan sekalipun, Yusuf tidak mudah mengumbar perasaan atau emosinya. Kematangan emosi Yusuf mampu membuat dirinya bersikap bijak, tidak terburu-buru mengambil keputusan dan mampu meneduhkan serta menghibur orang-orang di sekitarnya.

\section{Kemampuan dalam Menghadapi Kesulitan (Adversity Quotient).}

Adversity Quotient (AQ) merupakan suatu teori yang dikembangkan oleh seorang konsultan bisnis yang dikenal secara international yang bernama Paul G. Stoltz. AQ 
menggabungkan riset psikologi koqnitif, psiko-neuroimunologi dan neurofisiologi untuk membentuk suatu gambaran lengkap tentang cara manusia dalam menghadapi kesulitan. Banyak orang menghindari suatu kesulitan, tetapi dalam AQ kesulitan justru merupakan sebuah tantangan yang akan menjadikan hidup lebih hidup. ${ }^{9} \mathrm{AQ}$ merupakan ukuran bagaimana seseorang merespon suatu kesulitan dan menemukan cara keluarnya. Lebih jauh lagi, AQ adalah seperangkat alat bantu ilmiah untuk memperbaiki cara anda menghadapi kesulitan. ${ }^{10}$

Paul G Stolz membedakan 3 tingkatan AQ dalam masyarakat: ${ }^{11}$ Tingkat Quitrers (orang yang berhenti), quitrers adalah orang yang paling lemah AQ nya. Ketika ia menghadapi masalah ia langusung berhenti dan menyerah. Tingkat Campers (orang yang berkemah), orang yang memiliki tingkat Campers memiliki AQ sedang. Ia merasa cukup dan puas dengan apa yang dicapainya dan ia tidak ingin lebih maju. Tingkat Climbers (orang yang mendaki), climbers adalah orang yang ber-AQ tinggi dengan kemampuan dan kecerdasan yang tinggi untuk dapat bertahan menghadapi kesulitan dan mampu mengatasi tantangan hidup.

Dalam Alkitab sejak Kejadian 37 - 50, diceritakan bagaimana Yusuf banyak mengalami kesulitan-kesulitan sebelum ia mencapai kesuksesan dalam kehidupan sebelumnya. Kesuksesan yang diperoleh Yusuf tentunya tidak terlepas dari campur tangan dan penyertaan Tuhan kepadanya. Roh Tuhanlah yang memberikan kekuatan, pengertian, hikmat, kebijaksanaan dan menuntun Yusuf sehingga memperoleh keberhasilan dalam hidupnya. Ulasan mengenai kemampuan Yusuf dalam menghadapi kesulitan, beberapa telah dibahas dalam ulasan terdahulu, ketika membahas Kecerdasan Spiritual, Emosional, maupun Intelektual yang ada pada diri Yusuf. Beberapa kesulitan yang dihadapi oleh Yusuf dan bagaimana cara ia mengatasi atau menghadapinya, antara lain :

Kesulitan hidup Yusuf dimulai ketika Yusuf dua kali memperoleh mimpi dari Tuhan dan menyampaikan mimpinya itu kepada saudara-saudaranya dan juga orangtuanya, maka marahlah saudara-saudaranya itu dan mereka semakin membencinya. Namun mimpinya itu merupakan hal yang membuat ia mempercayai Tuhan, bahwa Tuhan kelak akan menjadikan dia sebagai

${ }^{9}$ Miarti Yoga, Adversity Quotient - Agar Anak Tak Gampang Menyerah (Solo: Tiga Serangkai, 2016), 18.

${ }^{10}$ Agus Nggermanto, Qantum Quotient-Kecerdasan Quantum (Bandung: Yayasan Nuansa Cendekia, 2001), 83.

${ }^{11}$ Miarti Yoga, Adversity Quotient (Solo: Tinta Medina, 2016), 29. 
pemimpin atas saudara-saudaranya, bahkan orang tuanya. Pernyataan Tuhan melalui mimpinya itulah yang dipakai oleh Yusuf sebagai sebuah visi dari Tuhan bahwa kelak Tuhan akan memberikan kesuksesan untuk menjadi pemimpin atau seseorang yang lebih dari saudarasaudaranya. Mimpi itulah yang menjadi kekuatan bagi Yusuf untuk mampu bertahan dalam menghadapi kebencian saudara-saudaranya dan penderitaan yang lainnya.

Ketika Yusuf ditangkap oleh saudara-saudaranya, kemudian jubahnya yang mahal dan indah ditanggalkan kemudian dilemparkan ke dalam sumur kosong, pastilah semua itu membuat Yusuf sangat terkejut dan mungkin juga marah, sangat sedih, kecewa, ketakutan dan putus asa. Cara yang dipakai oleh Yusuf dalam menghadapi kesulitan ini ialah dengan mengendalikan emosinya untuk tidak mengeluarkan perkataan yang membuat saudara-saudaranya tersulut emosinya sehingga bisa saja mereka membunuhnya.

Alkitab tidak menceritakan bagaimana reaksi Yusuf ketika ia dijual kepada saudagarsaudagar dar Median, kemudian mengikuti para saudagar itu selama perjalanan sehingga ia sampai di rumah Potifar. Mungkin Yusuf hanya pasrah dan menuruti segala apa yang diperintahkan oleh para saudagar itu, tetapi satu hal yang diyakini oleh Yusuf, dimana ia tetap berpegang pada visi Tuhan yang telah disampaikan melalui mimpinya. Pegangan terhadap pernyataan Tuhan itulah yang membuat ia terus mempercayai bahwa dalam keadaan apapun dan dimana ia ditempatkan pastilah Tuhan menolong dia.

Seorang yang bersedih hati tidak mungkin bisa bekerja dengan baik, tetapi yang dilakukan Yusuf dalam menghadapi keadaan hidupnya yang sulit, ia terus bekerja dengan rajin, sehingga Tuhan menyertai Yusuf dan membuat segala yang dilakukannya berhasil. Sikap positip dari Yusuf dalam menghadapi kesulitan hidup sebagai seorang pelayan di rumah Potifar, yaitu dengan bekerja dengan sunguh-sungguh, rajin, jujur dan baik adalah cara Yusuf untuk menyikapi keadaan dan juga melupakan kesedihannya. Kesulitan lain yang dihadapi Yusuf di rumah Potifar adalah ketika ia harus menghadapi godaan dari isteri Potifar untuk berbuat dosa perzinahan. Hal ini bukanlah sesuatu yang mudah untuk dihadapi, karena ia menghadapi seorang majikan yang mengajaknya untuk melakukan perzinahan. Tetapi Yusuf memilih tetap setia dan takut akan Tuhan dan ia menolak keinginan isteri Potifar. Dua hal yang dilakukan oleh Yusuf dalam menolak keinginan isteri Potifar, pertama dengan perkataan : "Dengan bantuanku tuanku itu tidak lagi mengatur apa yang ada di rumah ini dan ia telah menyerahkan segala miliknya pada 
kekuasaanku, bahkan di rumah ini ia tidak lebih besar kuasanya dari padaku, dan tiada yang tidak diserahkannya kepadaku selain dari pada engkau, sebab engkau isterinya. Bagaimanakah mungkin aku melakukan kejahatan yang besar ini dan berbuat dosa terhadap Allah?" (Kejadian 39:8-9). Kedua, ketika Yusuf hendak dipaksa oleh isteri Potifar sambil memegang bajunya, ia melarikan diri sampai bajunya tertinggal ditangan isteri Potifar. Kesulitan yang dihadapi oleh Yusuf untuk untuk menghindari perzinahan dengan isteri Potifar memang dapat teratasi, tetapi justru Yusuf harus mengalami fitnahan dan harus mengalami kesusahan baru, yaitu dipenjara.

Mungkin pada awal-awalnya Yusuf merasa sedih melihat perjalanan hidupnya yang tak kunjung berakhir dari kesulitan. Tetapi Yusuf sudah memiliki pengalaman pada saat ia dijual kepada Potifar dan kemudian dijadikan orang yang dipercaya oleh tuannya untuk mengurus segala keperluan tuannya dan juga kebutuhan rumah tangganya. Ketika Yusuf dipenjara, ia tidak mau memperlihatkan kesedihannya dan ia tetap melakukan tigas-tugas yang diserahkan oleh kepala penjara kepadanya dengan baik. Ia juga bersikap baik kepada tahanan yang lain sebagaimana yang ia lakukan kepada juru minuman dan juru roti raja. Kesungguhan Yusuf dalam melakukan semua pekerjaannya ini membuat kepala penjara melihat bahwa Yusuf adalah seorang yang disertai Tuhan dan mendapatkan kasih-Nya sehingga apa saja yang ia lakukan dibuat Tuhan berhasil. Apa yang dilakukan oleh Yusuf membuat kepala penjara mengasihi Yusuf dan memberikan kepercayaan kepada Yusuf untuk mengurus semua tahanan dan juga keperluan para tahanan tanpa ia harus mencampurinya.

Kehidupan Yusuf memang telah berubah. Hanya dalam hitungan menit ketika ia mengartikan mimpi raja Firaun, tiba-tiba kehidupan Yusuf berubah dari seorang tahanan menjadi seorang yang dipercaya raja untuk menjadi penguasa atas seluruh tanah Mesir. Secara materi kehidupan Yusuf pastilah sangat nyaman, bahkan jauh lebih nyaman dari Potifar atau kepala Penjara. Namun dari sisi tanggung-jawab, Yusuf harus menghadapi tugas yang berat. Ia harus mengumpulkan persediaan bahan makanan di masa tujuh tahun kelimpahan sebagai persiapan menghadapi masa tujuh tahun kelaparan. Dengan hikmat dan tuntunan dari Tuhan, Yusuf melakukan strategi dan menyusun rencananya serta aksi yang dilaksanakannya. 


\section{Kecerdasan Spiritual (Spiritual Intelligence/Spiritual Quotient).}

Kecerdasan spiritual adalah kecerdasan jiwa yang dapat membantu seseorang membangun dirinya secara utuh. Kecerdasan spiritual berasal dari dalam hati, menjadikan kita kreatif ketika dihadapkan pada masalah pribadi, dan mencoba melihat makna yang terkandung di dalamnya berdasarkan ajaran agama, serta menyelesaikannya dengan baik agar memperoleh ketenangan dan kedamaian hati. Kecerdasan spiritual membuat inividu mampu memaknai setiap kegiatannya sebagai suatu ibadah.

Kecerdasan-kecerdasan yang dimiliki oleh Yusuf, semata-mata bukan dimulai dari kecerdasan Intelektualnya, tetapi dari catatan Alkitab mengenai perjalanan hidup Yusuf yang terdapat dalam Kejadian 37 - 50, nampak jelas bahwa Yusuf disertai oleh Tuhan karena ia adalah orang yang takut akan Tuhan. Takut akan TUHAN adalah permulaan pengetahuan, tetapi orang bodoh menghina hikmat dan didikan. (Amsal 1:7). Kecerdasan Spiritual yang dimiliki Yusuf tidaklah muncul begitu saja karena kemaampuannya sendiri, tetapi ada faktor lain, yaitu dari keteladanan dalam diri orangtua dan nenek moyangnya serta kemauannya untuk belajar dan meneladaninya. Sebagai seorang remaja yang telah berumur tujuh belas tahun, Yusuf pasti sudah bisa mengerti dan memahami cerita-cerita tentang nenek moyangnya, yaitu Ishak dan Abraham. Yusuf pasti tahu apa yang difirmankan dan dijanjikan Tuhan kepada Abraham, yaitu tentang janji-janji Tuhan sebagaimana yang di Firmankan Tuhan dalam Kejadian 12:1-3. Yusuf pasti juga tahu cerita tentang bagaimana kakek buyutnya itu dengan taat dan iman kepada Tuhan membawa Ishak untuk dijadikan korban persembahan sesuai yang diperintahkan Tuhan. (Kejadian 22). Semua hasil akhir dari kesetiaan dan ketaatan Abraham pastilah dimengerti dengan baik oleh Yusuf. Tidak hanya itu tapi Yusuf juga mengerti bagaimana kehidupan Abraham, Ishak dan orangtuanya dalam mengasihi Tuhan. Bagaimana mereka senantiasa menaikan ungkapan kasih mereka melalui mezbah persembahan. Semuanya ini tentunya melekat kuat dalam ingatan dan pikiran Yusuf.

Ketika Yusuf memperoleh mimpi dari Tuhan, yaitu mimpi tentang berkas gandum (Kejadian 37:7) dan tentang matahari, bulan dan ke sebelas bulan yang sujud kepadnya (Kejadian 37:9), pastilah Yusuf menganggap bahwa mimpi yang diperolehnya bukanlah merupakan mimpi biasa, tetapi merupakan visi dari Tuhan mengenai masa depan Yusuf yang akan menjadi pemimpin dari saudara-saudaranya, bahkan kedua orang tuanya. Kedua mimpi yang diperoleh 
Yusuf ketika berusia tujuh belas tahun ini merupakan "titik awal" dari Kecerdasan Spiritual yang dimiliki Yusuf. Keteladanan orang tua dan nenek moyangnya serta mimpinya merupakan dua hal yang membuat ia mempercayai, bahwa mimpinya merupakan visi dari Tuhan untuk masa depannya. Hal ini menyebabkan ia tetap kuat dan tekun ketika harus mengalami penderitaan sejak dijual oleh saudara-saudaranya, mengalami kehidupan di penjara bahkan sampai menjadi penguasa di Mesir.

Kecerdasan Spiritual yang dilatih secara terus menerus menjadikan Yusuf memiliki karakter, sikap dan moral yang sangat luar biasa, baik di hadapan Tuhan maupun manusia. Kecerdasan Spiritualnya menjadikan Yusuf sebagai seorang yang takut akan Tuhan dan sungguhsungguh dalam menjaga kekudusan hidupnya. Yusuf adalah seorang pemuda yang manis sikapnya dan elok parasnya dan mungkin saat itu masih berumur sekitar delapan belas tahunan, pastilah mempunyai nafsu seksual yang menggelora. Sebagai seorang yang sangat di percaya oleh Potifar untuk mengatur rumah tangganya, Yusuf memiliki kesempatan yang luas untuk menggunakan kekuasaannya di dalam rumah itu, bahkan kalau saja ia mau menuruti ajakan isteri Potifar untuk berbuat dosa perzinahan, mungkin tidak ada orang lain yang tahu. Kematangan Spiritual dari Yusuf yang masih muda mampu menolak ajakan untuk berbuat dosa, sekalipun Yusuf harus menanggung resiko dipenjara. Kalau saja Yusuf tidak membangun kehidupan kerohaniannya, mungkin dengan mudah Yusuf tergoda bujuk rayu isteri Potifar dan Alkitab akan mencatat cerita yang berbeda tentang Yusuf. Kematangan Spiritual Yusuf menunjukan kecerdasan spiritualnya, sehingga ia mampu menolak perbuatan yang tidak dikehendaki oleh Tuhan, sekalipun ia memiliki banyak kesempatan.

Sekalipun Yusuf mengalami kesusahan ketika ia harus hidup di dalam penjara, Yusuf tetap menjaga sikapnya sehingga penyertaan Tuhan tetap ada seperti halnya ketika ia di rumah Potifar. Kejadian 9:21 Tetapi TUHAN menyertai Yusuf dan melimpahkan kasih setia-Nya kepadanya, dan membuat Yusuf kesayangan bagi kepala penjara itu. Sikap, karakter dan moral yang baik pada diri Yusuf tidak dapat menghilang sekalipun ia hidup terkurung di dalam penjara. Kepala penjara melihat semuanya yang ada pada diri Yusuf sehingga ia mempercayakan segala pekerjaan di dalam penjara.

Ketika Yusuf melihat juru minuman dan juru roti raja yang sama-sama di penjara sedang bermuram durja, Yusuf bisa merasakan kesedihan kedua orang itu dan berusaha 
membantunya. Dengan rendah hati,Yusuf mengatakan kepada mereka: "Bukankah Allah yang menerangkan arti mimpi? Ceritakanlah kiranya mimpimu itu kepadaku." (Kejadian 40:8). Yusuf tidak menyombongkan dirinya bahwa ia mampu mengartikan mimpi itu, tetapi Yusuf meninggikan Tuhan, bahwa Tuhanlah yang mampu mengartikan mimpi itu. Hal ini menggambarkan kematangan atau kecerdasan spiritual Yusuf sebagai orang yang memiliki sikap rendah hati dan meninggikan Tuhan. Kematangan spiritual Yusuf inilah yang membuat Tuhan menyertai dan mengasihi Yusuf dengan memberikan kemampuan untuk mengartikan mimpi dari juru minum dan juru roti raja. Apa yang diartikan oleh Yusuf dari mimpi ke dua orang itu ternyata semuanya tepat terjadi. Namun meskipun juru roti yang telah mengalami pembebasan melupakan janjinya pada Yusuf, ia tidak menjadi sakit hati atau bersikap yang mengumbar emosinya. Kecerdasan spiritual yang ada pada diri Yusuf ternyata juga membuat dirinya memiliki sikap mengendalikan emosinya dengan baik.

Kemampuan Yusuf ketika mengartikan mimpi juru minuman raja, akhirnya sampai kepada Firaun atas saran juru minum raja, ketika semua ahli yang dapat mengartikan mimpi tidak dapat mengartikan mimpi Firaun dengan benar. Saat Yusuf dipanggil oleh Firaun dari penjara untuk mengartikan mimpinya, ia tidak menyombongkan diri, tetapi tetap meninggikan dan mengandalkan Tuhan. Ketika Firaun menceritakan mimpinya, Yusuf mengatakan kepada Firaun: "Bukan sekali-kali aku, melainkan Allah juga yang akan memberitakan kesejahteraan kepada tuanku Firaun." (Kejadian 41:16). Kerendahan hati Yusuf yang dicerminkan dari perkataannya, sama dengan yang diucapkan ketika ia mengartikan mimpi juru minum dan juru roti di dalam penjara. Hal ini menunjukan kematangan atau kecerdasan spiritual yang dimiliki Yusuf.

"Semakin banyak kita menyesuaikan diri kita dengan teladan Kristus dalam hidup kita, semakin banyak kemajuan yang kita kerjakan di jalan ke-Ilahian dan kekudusan Kristen”. (Madam Guyon). ${ }^{12}$ Dari ulasan diatas mengenai Kecerdasan Spiritual Yusuf, terlihat bahwa kecerdasan spiritual Yusuf karena ia mau belajar dan meneladani kehidupan kerohanian orangtua dan nenek moyangnya. Kehidupan spiritualnya yang taat dan takut akan Tuhan membuat Yusuf mengalami keberhasilan demi keberhasilan karena Tuhan senantiasa menyertai kehidupannya. Dari pengalaman-pengalaman hidupnya, Yusuf mampu mengembangkan kecerdasan spiritualnya

${ }^{12}$ Steven D. Francis, Yusuf-Yusuf Dalam Generasi Tuhan (Jakarta: Yayasan Pekabaran Injil "IMMANUEL," 2000), 44. 
yang membuat ia mampu mengendalikan emosinya ketika menghadapi hal-hal buruk, serta tetap percaya bahwa Tuhan senantiasa menyertai kehidupannya.

\section{KESIMPULAN}

Dari ulasan tentang Kecerdasan yang dimiliki oleh Yusuf, terlihat bahwa Yusuf adalah seorang yang memang disertai dan senantiasa mendapatkan kasih dari Tuhan. Kecerdasan yang dimiliki oleh Yusuf, tidak dimulai dari kecerdasan inteligensinya, tetapi kemauan Yusuf untuk meneladani dan belajar dari orangtua dan nenek moyangnya (Abraham dan Ishak), membuat kecerdasan spiritualnya berkembang lebih dahulu, sehingga Yusuf menjadi orang yang takut akan Tuhan, setia dan mengasihi Allah. Beberapa kali dituliskan dalam Alkitab, bahwa Yusuf disertai Tuhan sehingga apa saja yang diperbuatnya senantiasa berhasil. Pernyataan ini menegaskan bahwa keberhasilan Yusuf dimulai dari kehidupan kerohaniannya atau Kecerdasan Spiritual yang pada akhirnya Roh Tuhan menuntun Yusuf untuk memiliki kecerdasan-kecerdasan yang lain dan berkembang semakin baik.

Selain Kecerdasan Spiritualnya, Kecerdasan Emosi (EQ) dan Kecerdasannya dalam menghadapi kesulitan (AQ), memampukan Yusuf untuk menghadapi kesulitan-kesulitan pada masa kehidupannya yang buruk sampai akhirnya raja Firaun melihat kelebihan yang dimiliki Yusuf dan melihat Roh Allah yang menyertai Yusuf sehingga Yusuf diangkat menjadi penguasa atas seluruh tanah Mesir yang diberi tanggung-jawab untuk menyiapkan pengumpulan bahan pangan ketika menghadapi masa tujuh tahun kelaparan yang terjadi di Mesir. Kecerdasan Inteligensi dan Kreativitasnya memampukan Yusuf untuk melaksanakan tugas yang dipercayakan raja untuk mengumpulkan bahan pangan yang digunakan pada masa kelaparan, bahkan pada masa kelaparan Yusuf dapat melihat peluang untuk membeli tanah seluruh rakyat Mesir dan juga memberikan benih untuk ditanam di lahan rakyat mesir yang telah dijual kepada raja, tetapi mereka harus menyerahkan seperlima hasil panennya kepada raja. Ketetapan ini pada akhirnya menjadi peraturan di bangsa Mesir. Kecerdasan multiple yang dimiliki oleh Yusuf menggambarkan Karakter yang dimilikinya dan memampukan Yusuf menjadi pemimpin yang cerdas dan bijaksana serta takut akan Tuhan. Dengan karakter dan Kecerdasannya Yusuf mampu menggenapi segala rancangan Tuhan dalam hidupnya. (Kejadian 50:20). 


\section{DAFTAR PUSTAKA}

Amstrong, Thomas. Sekolah Para Juara. Bandung: PT. Mizan Pustaka, n.d.

Francis, Steven D. Yusuf-Yusuf Dalam Generasi Tuhan. Jakarta: Yayasan Pekabaran Injil "IMMANUEL," 2000.

Gidion, Gidion. "STUDI BIBLIKA KORELASI TEOLOGI PAULUS DAN TEOLOGI YAKOBUS TENTANG IMAN DAN PERBUATAN IMAN." Shift Key: Jurnal Teologi dan Pelayanan 8.2 (2018).

Nasional, Departemen Pendidikan. Pusat Bahasa, Kamus Besar Bahasa Indonesia. Jakarta: PT. Gramedia Pustaka Utama, 2015.

Nggermanto, Agus. Qantum Quotient-Kecerdasan Quantum. Bandung: Yayasan Nuansa Cendekia, 2001.

Swindoll, Charles R. Yusuf - Seorang Yang Berintergritas Dan Pengampun. Jakarta: Nafiri Gabriel, 2011.

Wahyudi, Josua Iwan. Emotion For Success. Bandung: Visi Press, 2010.

Yoga, Miarti. Adversity Quotient. Solo: Tinta Medina, 2016.

. Adversity Quotient - Agar Anak Tak Gampang Menyerah. Solo: Tiga Serangkai, 2016.

Zed, Mestika. Metode Peneletian Kepustakaan. Jakarta: Yayasan Obor Indonesia, 2008. 